\title{
A novel late embryogenesis abundant protein and peroxidase associated with black point in barley grains
}

\author{
Timothy J. March, Jason A. Able, Carolyn J. Schultz and Amanda J. Able \\ School of Agriculture, Food \& Wine, The University of Adelaide, Waite Campus, Glen Osmond, \\ South Australia, Australia
}

Black point of barley grain is a disorder characterised by a brown-black discolouration at the embryo end of the grain. Black point is undesirable to the malting industry and results in significant economic loss annually. To identify proteins associated with barley black point we uti-

Received: May 10, 2007 Revised: June 13, 2007 Accepted: July 25, 2007 lised a proteomic approach with 2-DE to compare proteins from whole grain samples of black pointed and healthy grain. From this comparison two condition-specific proteins were identified: a novel $75 \mathrm{kDa}$ late embryogenesis abundant (LEA) protein and a barley grain peroxidase 1 (BP1) that were specifically more abundant in healthy grain and black pointed grain, respectively. Although LEA protein was less abundant in black pointed grain, LEA gene expression was greater suggesting protein degradation had possibly occurred in black pointed grain. Similarly, the increase in BP1 in black pointed grain could not be explained by gene expression. Western blot analysis also revealed that the identified LEA protein is biotinylated in vivo. The role that each of these proteins might have in black point development is discussed.

\section{Keywords:}

Barley black point / Grain development / Hordeum vulgare

\section{Introduction}

Black point is a disorder which affects both barley (Hordeum vulgare L.) and wheat (Triticum aestivum L.) grain and is characterised by a brown-black discolouration at the embryo end of the grain. Discolouration of barley grain occurs predominately in the husk tissue (lemma and palea) with some discolouration of the germ aleurone tissue [1].

Black point affected barley grain is unacceptable to the malting industry with the current limit set at 10\% of grains per tested sample in Australia (http:// ezigrain.abb.com.au/receivalstandards/receivalstandards.asp).

Correspondence: Dr. Amanda J. Able, School of Agriculture, Food \& Wine, The University of Adelaide, PMB1, Glen Osmond, South Australia 5064, Australia

E-mail: amanda.able@adelaide.edu.au

Fax: +61-8-8303-7109

Abbreviations: BP1, barley peroxidase 1; LEA, late embryogenesis abundant
Affected malting barley is traded as feed barley attracting a discounted price which results in significant economic losses annually.

Historically, black point of wheat grain has been associated with the colonisation of the grain by a range of fungi including Alternaria alternata [2, 3], Fusarium spp. [4] and Bipolaris sorokiniana [5]. However, studies describing these associations have also isolated fungi from healthy grains. Furthermore, an Australian study found black point symptoms in wheat grains can develop in the absence of any fungal infection [6]. In barley, studies have reported no correlation between fungal colonisation and black point [7, 8].

Environmental conditions have been confirmed as triggers for black point formation in cereals. High humidity and rainfall during grain development has been linked to increased incidence of black point in barley [9]. In wheat, rainfall during the milk to dough grain development stage is most critical for the development of black point [10, 11]. These conditions are favourable for fungal colonisation but since no clear association has been found, black point might have a physiological basis. 
Developments in understanding the mechanisms of black point formation in wheat suggest that the black discolouration is a result of enzymatic oxidation of phenolic compounds within the grain. Black point was reproduced in vitro when grains were soaked in a phenolic acid solution and then transferred into hydrogen peroxide [6]. The requirement for hydrogen peroxide suggests peroxidase enzymes were involved in the discolouration reaction.

Peroxidase enzymes are able to catalyse the oxidation of a range of substrates into dark coloured endproducts including ferulic and $p$-coumaric acid, provided hydrogen peroxide reduces the substrate first [12]. Ferulic and $p$-coumaric acid are the main phenolic acids found in monocotyledonous plants with ferulic acid constituting more than $90 \%$ of total phenolic acid in wheat flour [13]. Comparisons between a black point susceptible and tolerant durum wheat variety has found that the susceptible variety contained higher levels of ferulic acid and increased activity of phenylalanine ammonia lyase (PAL), an enzyme involved in phenolic acid biosynthesis [14].

The above studies suggest that several biochemical pathways involving the production and oxidation of phenolic compounds might be involved in black point formation in wheat. Based on this rationale, a broad-based experimental approach such as 2-DE to identify individual enzymes that are involved in this process would be advantageous.
A recent study using 2-DE compared protein expression between healthy and black pointed wheat grain [15]. This study presented a link between the expression of stressrelated proteins including peroxidases and black point symptoms. To date several studies have analysed the proteome of the barley grain during grain fill and during micromalting [16-18], however, none have examined black point related protein expression.

We have utilised 2-DE techniques to compare black point affected and healthy barley grain to identify proteins associated with the presence and absence of black point formation in barley grain. The role that the identified proteins might play in black point development is discussed.

\section{Material and methods}

\subsection{Barley tissue samples}

H. vulgare (cv. Sloop) was field grown during the 2004 season near Millicent, South Australia (latitude 37.49'S, longitude 140.27'E) and mechanically harvested at maturity. Based on visual assessment, mature seeds were categorised into black pointed grain (Fig. 1A) and clean grain samples (Fig. 1B).
A

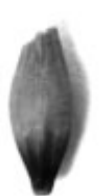

c

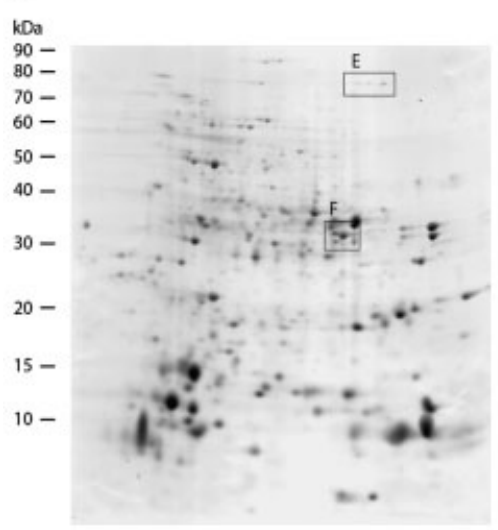

pl 3

E

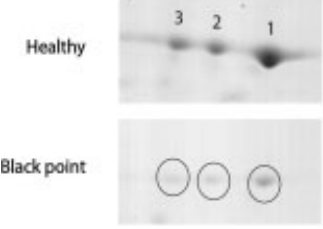

F

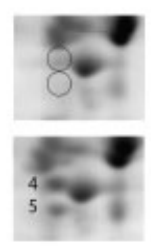

B

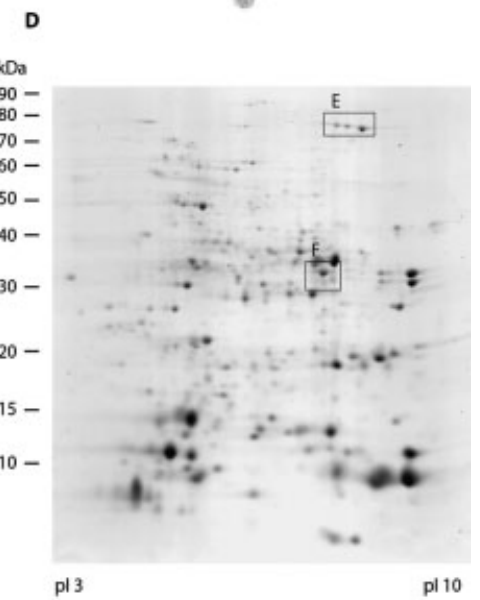

G

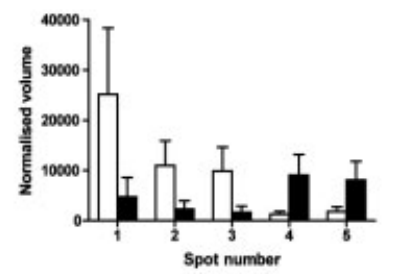

Figure 1. Identification of proteins associated with black point. Proteins were extracted from black pointed $(A)$ and healthy $(B)$ grain samples and separated using 2-DE. Representative gel images from black pointed grain (C) and healthy grain (D) are shown. Boxed regions highlight differences between the samples with three proteins identified as being more abundant in healthy grain (E) and two proteins identified as more abundant in black-pointed grain (F). Quantification of the normalised spot volumes for healthy (white bars) and black pointed (black bars) samples confirmed this observation (G). Data shown are the mean \pm SE of two gel replicates of three biological replicates $(n=6)$. 
Sloop is a major Australian malting cultivar with mid- to early-maturity and is considered to be susceptible to black point.

\subsection{Protein extraction}

Seed proteins were extracted as described previously [16] with all steps carried out at $4^{\circ} \mathrm{C}$ unless otherwise stated. Barley seeds (4 g) were ground to flour with liquid nitrogen using a mortar and pestle. To isolate the proteins, the flour was shaken for $30 \mathrm{~min}$ at $100 \mathrm{rpm}$ in a solution containing $5 \mathrm{mM}$ Tris- $\mathrm{HCl}(\mathrm{pH} 7.5)$ and $1 \mathrm{mM} \mathrm{CaCl}_{2}$ buffer $(20 \mathrm{~mL})$. Insoluble materials were pelleted by centrifugation $(8000 \times \mathrm{g}$ for $30 \mathrm{~min}$ ). The supernatant was then collected and stored in $2 \mathrm{~mL}$ aliquots at $-20^{\circ} \mathrm{C}$ until required.

\subsection{2-DE}

Protein aliquots $(2 \mathrm{~mL})$ were precipitated with four volumes of acetone $\left(-20^{\circ} \mathrm{C}\right.$, overnight) and then collected by centrifugation $(10000 \times \mathrm{g}$ for $5 \mathrm{~min})$. Proteins were redissolved in a rehydration buffer ( $8 \mathrm{M}$ urea, $2 \%$ CHAPS, $0.5 \% \mathrm{v} / \mathrm{v}$ IPG buffer pH 3-10 (Amersham Biosciences, Uppsala, Sweden), $20 \mathrm{mM}$ DTT and a trace of bromophenol blue) with constant shaking at $100 \mathrm{rpm}$ for $3 \mathrm{~h}$. Protein concentration was determined using the $R C D C^{\mathrm{TM}}$ assay (BioRad, Hercules, CA, USA).

Protein samples $(500 \mu \mathrm{g}$ in $340 \mu \mathrm{L}$ of rehydration buffer) were used to rehydrate $18 \mathrm{~cm}$ IPG dry strips pH 3-10 and then focussed using an Ettan ${ }^{\text {TM }}$ IPGphor $^{\text {TM }}$ II IEF System (Amersham Biosciences). Focussing was performed for a total of $42000 \mathrm{~V} \cdot \mathrm{h}$ at $20^{\circ} \mathrm{C}$ as per the manufacturer's recommendations and consisted of the following steps: $6 \mathrm{~h}$ of passive rehydration $(0 \mathrm{~V}), 6 \mathrm{~h}$ of active rehydration $(30 \mathrm{~V})$, followed by $2 \mathrm{~h}$ at $300 \mathrm{~V}$, a gradient to $1000 \mathrm{~V}$ over $6 \mathrm{~h}$, and then a gradient to $8000 \mathrm{~V}$ over $3 \mathrm{~h}$, and finally $8000 \mathrm{~V}$ for $24000 \mathrm{~V} \cdot \mathrm{h}$. IPG strips were then equilibrated in equilibration buffer (6 M urea, 2\% SDS, 20\% glycerol and $50 \mathrm{mM}$ Tris- $\mathrm{HCl}, \mathrm{pH} 8.8$ ) containing $2 \% \mathrm{w} / \mathrm{v}$ DTT, for $20 \mathrm{~min}$ followed by equilibration buffer containing $2.5 \%$ iodoacetamide for a further $20 \mathrm{~min}$. The second dimension was performed using a PROTEAN ${ }^{\circledR}$ II xi 2-D Cell (BioRad) and hand-poured $10 \%$ Bis-Tris gels ( $\mathrm{pH}$ 6.4) with MES running buffer (Invitrogen, Carlsbad, CA, USA) as described previously [19]. Gels were run at a constant of $200 \mathrm{~V}$ for $5.5 \mathrm{~h}$. Proteins were stained using a modified colloidal CBB G-250 stain [20]. Two analytical replicates for three independent biological extracts were produced for both black pointed and healthy barley grain.

\subsection{Image analysis}

Gels were scanned using an ImageScanner (Amersham Biosciences) operated by the software, Lab-Scan 3.00 (Amersham Biosciences). Intensity calibration was carried out using an intensity stepwedge prior to gel image capture.
Image analysis was carried out using the ImageMaster 2D Elite 4.01 software (Amersham Biosciences). Gels were compared manually as well as using the spot detection mode. Spots were matched, then the background was subtracted using the average on boundary method and spot normalisation performed using the total spot volume method. Standard error was calculated for the normalised values and a paired Student $t$-test performed using GraphPad Prism 5 for Windows (GraphPad Software, San Diego, CA, USA). Spots consistently showing greater than two-fold difference with $p<0.05$ were excised from the gel for MS analysis.

\subsection{LC MS/MS and protein identification}

Protein identification was performed by the Hanson Institute Protein Core Facility (Adelaide, Australia) using MS/ MS analysis. Individual bands were excised, destained and subjected to in-gel tryptic digestion as described previously [21].

Extracted tryptic peptides were desalted on a $1 \times 5 \mathrm{~mm}$ $5 \mu \mathrm{m}$ C18 precolumn (LC-Packings) before separation on a $0.075 \times 100 \mathrm{~mm} 3 \mu \mathrm{m}$ Atlantis dC18 NanoEase analytical column (Waters, Milford, MA, USA) with an ACN gradient (5-70\% v/v over $45 \mathrm{~min}$ containing $0.1 \%$ formic acid w/v) at a flow rate of $200 \mathrm{~nL} / \mathrm{min}$ using a CapLC system (Waters). The eluted peptides were introduced into a Micromass QTOF2 mass spectrometer (Waters) through a NanoSpray source and ionised with $3 \mathrm{kV}$. A survey scan of the eluting material identified multiple charged species $(+2,+3$ and +4 charge states) with the most abundant selected for fragmentation and MS/MS analysis. Once sufficient signal was accumulated for each of the daughter-ion series, the system reverted to the survey scan mode to identify further multiple charged species of potential interest.

Following acquisition, MS/MS data were processed and analysed using ProteinLynx 2.0 software (Waters). De novo sequence tags were determined from the fragmentation data and used to search the National Centre for Biotechnology Information (http://www.ncbi.nlm.nih.gov/) nonredundant protein database (October 2006 release) for potential protein identification matches. To determine theoretical MW and $\mathrm{p} I$ values the compute $\mathrm{pI} / \mathrm{MW}$ tool was used (http:// www.expasy.org/tools/pi_tool.html).

\subsection{Western blot analysis}

For Western blots of 2-D gels, the electrophoresis method described in Section 2.3 was used except for the following changes. Protein samples $(150 \mu \mathrm{g})$ were used to rehydrate $7 \mathrm{~cm}$ IPG dry strips pH 3-10 (Amersham Biosciences). Focussing was performed for a total of $8164 \mathrm{~V} \cdot \mathrm{h}$ consisting of the following steps: $6 \mathrm{~h}$ of passive rehydration $(0 \mathrm{~V}), 6 \mathrm{~h}$ of active rehydration $(0 \mathrm{~V}), 300 \mathrm{~V}$ for $2 \mathrm{~h}, 30 \mathrm{~min}$ gradient to $1000 \mathrm{~V}, 80 \mathrm{~min}$ gradient to $5000 \mathrm{~V}$ then $5000 \mathrm{~V}$ for $3000 \mathrm{~V} \cdot \mathrm{h}$. The second dimension was performed using NuPAGE ${ }^{\circledR} 4$ 
12\% Bis-Tris ZOOM gels with MES buffer and an XCell SureLock $^{\mathrm{TM}}$ Mini cell gel tank (Invitrogen). Gels were electrophoresed at a constant $200 \mathrm{~V}$ for $40 \mathrm{~min}$.

Proteins were transferred to PVDF membrane using an XCell II ${ }^{\mathrm{TM}}$ Blot Module following the manufacturer's instructions (Invitrogen). The direct blue 71 membrane staining method was used to visualise transferred proteins [22]. Biotinylated peptides were detected using a 1:2000 dilution of streptavidin alkaline phosphatase (Sigma-Aldrich) and visualised via reaction with a nitroblue tetrazolium (NBT)/ bromo-4-chloro-3'-indolyphosphate p-toluidine (BCIP) NBT/ BCIP solution (Sigma-Aldrich) to yield a dark purple product.

\subsection{RNA extraction and Northern blot analysis}

Whole seeds were ground in liquid nitrogen using a mortar and pestle. RNA was extracted from ground tissue using the TRIzol $^{\circledR}$ reagent as per manufacturer's recommendations (Invitrogen). Total RNA (10 $\mu \mathrm{g})$ was separated on a $1.2 \%$ formaldehyde gel and blotted to $\mathrm{N}+$ membrane as per the manufacturer's recommendations (Amersham Biosciences). Probes for Northern analysis of barley peroxidase (BP1) and late embryogenesis abundant (LEA) were PCR amplified from cDNA that was prepared from grain RNA using SuperScript ${ }^{\circledR}$ II reverse transcriptase as per the manufacturer's instructions (Invitrogen). PCR conditions were $2 \mathrm{~min}$ at $94^{\circ} \mathrm{C}$; then 32 cycles of $30 \mathrm{~s}$ at $94^{\circ} \mathrm{C}, 30 \mathrm{~s}$ at $55^{\circ} \mathrm{C}$ and $1 \mathrm{~min}$ at $72^{\circ} \mathrm{C}$; followed by $10 \mathrm{~min}$ at $72^{\circ} \mathrm{C}$. Primers used to amplify the BP1 probe were $5^{\prime}$ CACACACAAAGGAGAGAGGAGATGGCTCG $3^{\prime}$ and $5^{\prime}$ TGGACGAACTCGCGCACGATGG $3^{\prime}$, for the LEA probe the primers were $5^{\prime}$ TCGACTCAGCCTGCCACTGA $3^{\prime}$ and 5' GTAGTCTCCAGTGGAGCCGAGCGT 3'. These primers yielded a product of 195 and 823 bp, respectively.

Probes were radioactively labelled with $\mathrm{P}^{32}$ (Amersham Biosciences) using the Ready-To-Go DNA Labelling Beads (Amersham Biosciences). Labelled probes were denatured for $2 \mathrm{~min}$ at $95^{\circ} \mathrm{C}$ and added to $20 \mathrm{~mL}$ of hybridisation buffer (0.5 $\mathrm{M} \mathrm{Na}_{2} \mathrm{HPO}_{4} \mathrm{pH} 7.2$, 7\% SDS and $1 \mathrm{mM}$ EDTA). Membranes were hybridised overnight in bottles at $65^{\circ} \mathrm{C}$ and then washed consecutively with 2,1 and $0.5 \times$ SSC containing $0.1 \%$ SDS for $15 \mathrm{~min}$ per wash at $65^{\circ} \mathrm{C}$. Washed membranes were exposed to Hyperfilm MP (Amersham Biosciences) for 3 days at $-80^{\circ} \mathrm{C}$.

\subsection{Obtaining the full length LEA sequence}

The GeneRacer kit (Invitrogen) was used to obtain the unidentified $3^{\prime}$ sequence of the identified LEA partial coding UniGene sequence Hv.10490 (Table 1) using 3'RACE. Total RNA was extracted from mature grain as per Section 2.7 and used to prepare cDNA. Amplification of the $3^{\prime}$ sequence was performed using a combination of the supplied primers and a primer designed to the $3^{\prime}$ region of the UniGene sequence Hv.10490 (5' CGCGCTCGGATTGACGGGAGACCAAACT $\left.3^{\prime}\right)$. The amplified fragment was cloned using the QIAGEN
PCR Cloning Kit (Qiagen) and sequenced by AgGenomics (Melbourne, Australia) using BigDye ${ }^{\mathrm{TM}}$ chemistry (Applied Biosystems). Sequence analysis was performed using the program Vector NTI Advance 10 (Invitrogen).

\section{Results}

\subsection{Production of a proteome map for black pointed and healthy grain}

To compare the proteome of black pointed and healthy grain (Figs. 1A and B) low salt extractable proteins were separated using 2-DE. CBB G-250 stained gel images were of high reproducibility between analytical and biological repetitions of the same sample (Figs. 1C and D). Comparison of black pointed and healthy gels identified three proteins significantly more abundant in healthy grain and two more abundant in black-pointed grain (Figs. 1E and F). In both cases, the difference in normalised volume was greater than twofold between black pointed and healthy samples (Fig. 1G).

Each of the three proteins more abundant in healthy grain were approximately $70 \mathrm{kDa}$ while their $\mathrm{p}$ Is were approximately 7.6, 7.9 and 8.1, respectively suggesting they were isoforms of the same protein. The two proteins more abundant in black pointed grain were 34 and $33 \mathrm{kDa}$, respectively while they shared the same $\mathrm{p} I$ of 7.2.

\subsection{Identification of proteins using MS/MS}

For the three $70 \mathrm{kDa}$ proteins, a total of four de novo peptide sequences (common to all) were obtained by MS/MS analysis (Fig. 2). Using the tblastn program (http:// www.ncbi.nlm.nih.gov/BLAST/), two of the peptides identified matched to a translated $933 \mathrm{bp}$ barley UniGene sequence Hv.10490 (Table 1). This UniGene sequence did not contain a stop codon. The longest partial ORF predicted from this sequence displayed 33\% amino acid sequence similarity to an LEA domain containing protein from rice (XP_464846). The remaining two identified peptides did not match to this identified UniGene sequence but matched to the full length cDNA clone isolated (Fig. 3A).

For the 34 and $33 \mathrm{kDa}$ proteins, MS/MS identified six de novo peptides for each spot and database searching identified both spots as barley grain peroxidase 1 with a $20.7 \%$ coverage (Table 1). BP1 is well characterised in barley and its crystal structure has been resolved [23].

\subsection{Characterisation of a novel biotinylated barley LEA protein}

Using $3^{\prime}$ RACE and the partial coding sequence from UniGene Hv.10490 (933 bp), a full length cDNA clone of 2322 bp was obtained which encoded a protein 518 aa residues in length (Fig. 3A, GenBank accession EF535810) with a predicted size of $52 \mathrm{kDa}$ and $\mathrm{p} I$ of 7 . Within the full sequence 
Table 1. Identification of proteins with a greater than two-fold normalised volume difference between healthy and black pointed barley grains. Proteins identified as being significantly different (as per Fig. 1) were subjected to MS/MS analysis and the de novo peptides matched to the NCBI nonredundant protein database

\begin{tabular}{|c|c|c|c|c|c|c|c|c|c|}
\hline Spot & $\begin{array}{l}\text { Protein } \\
\text { identified }\end{array}$ & Accession & Identified peptides & $\begin{array}{l}\text { Observed/ } \\
\text { theoretical } \\
\mathrm{MW}(\mathrm{kDa})^{\mathrm{b})}\end{array}$ & $\begin{array}{l}\text { Observed/ } \\
\text { theoretical } \\
\mathrm{p} /{ }^{\text {b) }}\end{array}$ & Score ${ }^{\mathrm{c})}$ & $\begin{array}{l}E \\
\text { value }^{\mathrm{c})}\end{array}$ & $\begin{array}{l}\text { Volume } \\
\text { ratio } \\
\mathrm{BP}: \mathrm{H}^{\mathrm{d})}\end{array}$ & $\begin{array}{l}\% \text { Cover- } \\
\text { age }^{\text {e) }}\end{array}$ \\
\hline 1 & $\begin{array}{l}\text { Putative LEA } \\
\text { protein }\end{array}$ & EF535810 & $\begin{array}{l}\text { 1. EEGQGGLGLEEIGK } \\
\text { 2. GTNAPAGGTVASSR } \\
\text { 3. EVTVSTGGTAAEYAK } \\
\text { 4. DVTLSTGAQAAQK }\end{array}$ & $75 / 52$ & $7.6 / 7$ & $\mathrm{n} / \mathrm{a}$ & $\mathrm{n} / \mathrm{a}$ & $1: 5$ & 10.8 \\
\hline 2 & $\begin{array}{l}\text { Putative LEA } \\
\text { protein }\end{array}$ & EF535810 a) & $\begin{array}{l}\text { 1. EEGQGGLGLEEIGK } \\
\text { 2. GTNAPAGGTVASSR } \\
\text { 3. EVTVSTGGTAAEYAK } \\
\text { 4. DVTLSTGAQAAQK }\end{array}$ & $75 / 52$ & $7.9 / 7$ & $\mathrm{n} / \mathrm{a}$ & $\mathrm{n} / \mathrm{a}$ & $1: 4$ & 10.8 \\
\hline 3 & $\begin{array}{l}\text { Putative LEA } \\
\text { protein }\end{array}$ & $E F 535810^{a)}$ & $\begin{array}{l}\text { 1. EEGQGGLGLEEIGK } \\
\text { 2. GTNAPAGGTVASSR } \\
\text { 3. EVTVSTGGTAAEYAK } \\
\text { 4. DVTLSTGAQAAQK }\end{array}$ & $75 / 52$ & $8.1 / 7$ & $\mathrm{n} / \mathrm{a}$ & $\mathrm{n} / \mathrm{a}$ & $1: 6$ & 10.8 \\
\hline 4 & $\begin{array}{l}\text { Barley grain per- } \\
\text { oxidase BP1 }\end{array}$ & Gl:2624498 & $\begin{array}{l}\text { 1. GAVVSCSDILALAAR } \\
\text { 2. YYIDLVNR } \\
\text { 3. DSVVVSGGPDYR } \\
\text { 4. KDIGLAAGLLR } \\
\text { 5. TPNVFDNK } \\
\text { 6. DIGLAAGLLR }\end{array}$ & $34 / 33$ & $7.2 / 6.5$ & 50.8 & $2 e-05$ & $7: 1$ & 20.7 \\
\hline 5 & $\begin{array}{l}\text { Barley grain per- } \\
\text { oxidase BP1 }\end{array}$ & GI:2624498 & $\begin{array}{l}\text { 1. GAVVSCSDILALAAR } \\
\text { 2. YYIDLVNR } \\
\text { 3. DSVVVSGGPDYR } \\
\text { 4. KDIGLAAGLLR } \\
\text { 5. TPNVFDNK } \\
\text { 6. DIGLAAGLLR }\end{array}$ & $33 / 33$ & $7.2 / 6.5$ & 50.8 & $2 e-05$ & $4: 1$ & 20.7 \\
\hline
\end{tabular}

a) EF535810 was submitted to GenBank by the authors and was derived from 3' RACE and sequence information for Hv.10490 (see Fig. 3A).

b) Observed MW and p/were taken from the position of the spot on the gel and the theoretical MW and p/determined using the calculate $\mathrm{MW} / \mathrm{p} /$ tool (http://www.expasy.org/tools/pi_tool.html).

c) Score and $E$-value was determined from protein blast against the nonredundant protein database (http://www.ncbi.nlm.nih.gov/ BLAST/).

d) The mean normalised spot volume $(n=6)$ shown as a ratio between black pointed (BP) and healthy $(\mathrm{H})$ grain samples.

e) The percent coverage of the matched protein by the MS/MS derived de novo peptide sequences.

the remaining two MS/MS de novo peptide fragments were identified (Fig. 3A), giving total sequence coverage of $10.8 \%$.

Because LEA proteins of a similar size identified in pea and soybean (65 and $68 \mathrm{kDa}$, respectively) are biotinylated in vivo $[24,25]$ and a potential atypical biotin binding site (GKF) was identified [26], Western blot analysis was performed on 2-D gels of healthy grain (Figs. 3B and C). The putative barley LEA protein isolated in this study bound streptavidin (Fig. 3C) indicating that this protein is also biotinylated in vivo.

\subsection{Transcript levels in healthy and black pointed grain}

To determine if the increased abundance of LEA in healthy grain and BP1 in black pointed grain was controlled by gene transcription, Northern blots were performed. Unexpectedly, gene expression levels for LEA were slightly higher in black pointed grain and could not account for the increased abundance of the LEA protein in healthy grain (Fig. 4A). BP1 gene expression was undetectable in both healthy and black pointed mature grain (Fig. 4B). However, BP1 gene expression has been shown to be present during the initial stages of grain development before down regulation at the dough stage in healthy grain (data not shown).

\section{Discussion}

Black point of barley and wheat grains has historically been associated with fungal colonisation of the grain [2-5]. However, evidence of fungal association with black point is often contradictory within the literature. Environmental condi- 
A

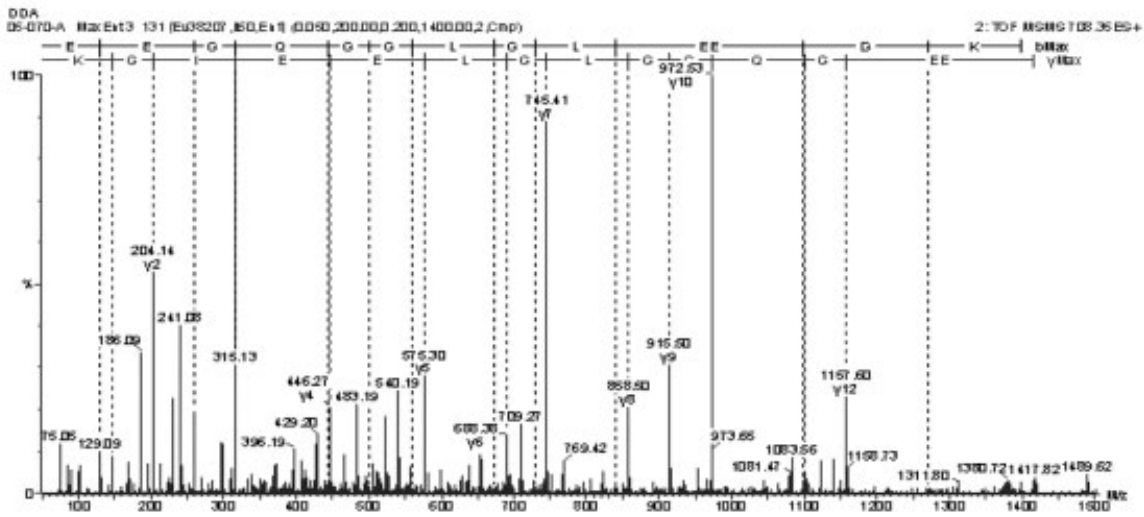

B
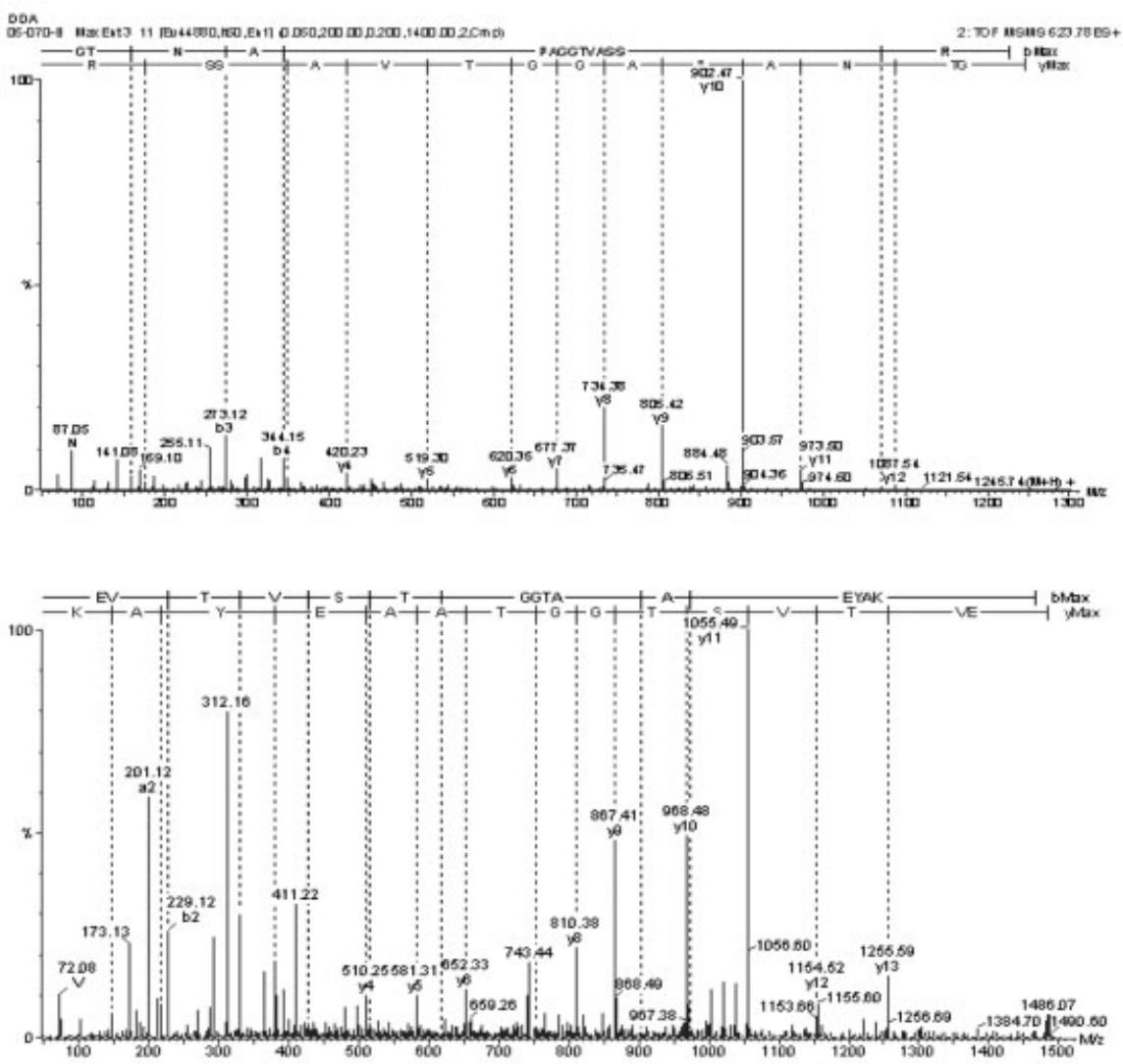

D

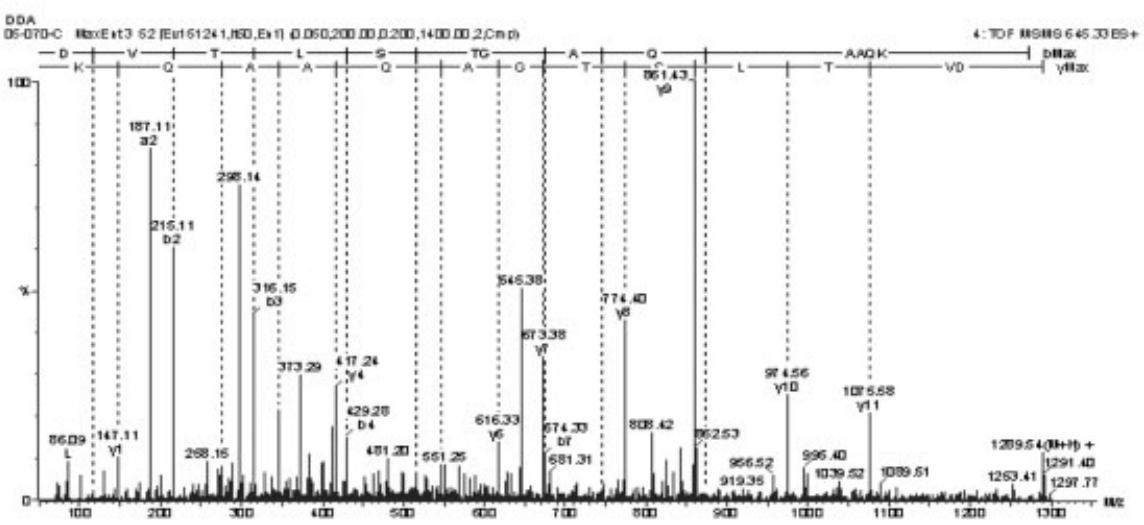

Figure 2. MS/MS analysis of the putative LEA protein. Each of the proteins identified (spots 1, 2 and 3 in Fig. 1) were excised from the gel and digested with trypsin then subjected to MS/ MS analysis. All three spots produced four common mass spectra in the +2 charge state, indicative of isoforms of the one protein. The spectra for the de novo sequences listed in Table 1 are shown for EEGQGGLGLEEIGK (A); GTNAPAGGTVASSR (B); EVTVSTGGTAAEYAK (C) and DVTLSTGAQAAQK (D). 
A

MASQQQSRKDAASKREEGQGGLGLEEIGKFRAEAQQHSADAIRAAQE RYNQNLQHGGGARGAVTVTQAPGATVVSYQEHKAIPEGAQQGRAHGH GTNAPAGGTTASSRGTELQHGAKQEEGRGHGTGHKEHKGSAAVTRAAD DKESAARGTNAPAGGTVASSRGAEKQHHTKQEEGRGHGAGHKEQKGSA AVTHATEDGGKEGHSARSAKDAAMHALGLTEDQTVGKGAGIKDAGAH GAHVHGHDAGHREQKGSDSAARTLGSTGDYVSAKGAEAKDAGAHGAO VTAEGTQEATATAAEYAKQAAAKAKEVTVSTGGTAAEYAKAAAEKAR EAALAAGKTTAEYTQQAAVKGKDVTVSTGGTAAEYAKTAAEMAKDAA LAAGKTTAEYTQQAAVKTKDVTLSTGAQAAQKAKEVTAVTAQKVAEY TKEMAEQGKATAAEVEEKAKEAAARAADKAEEPSLDTGSQAKGSAA RAADKTRDTAAQTMGRAKDATGETGDMTGSLTGQVKGHDRSHGAEGE

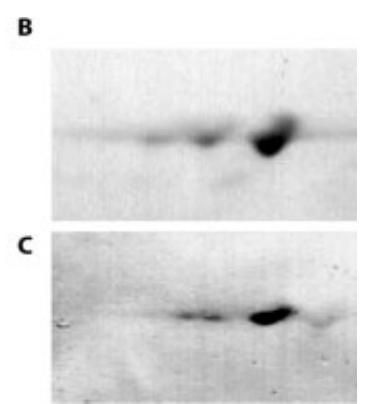

Figure 3. Characterisation of a LEA protein abundant in healthy grain. The entire coding region of the identified LEA protein was obtained using $3^{\prime}$ RACE. The derived amino acid sequence $(A)$ is shown with the peptides identified by MS/MS (from Fig. 2) underlined. Those underlined with a solid line were identified in the UniGene sequence Hv. 10490 while those underlined with a dotted line were identified in the additional sequence identified by $3^{\prime}$ RACE. To show that the LEA protein is biotinylated in vivo, a Western blot was prepared from a 2-D gel of healthy grain protein and stained for total protein (B) and then reprobed with a streptavadin antibody (C).
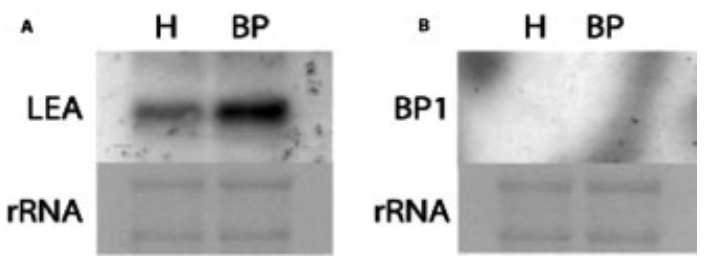

Figure 4. Northern blot analysis of LEA (A) and BP1 (B) from mature healthy $(H)$ and black pointed $(B P)$ grain. Ethidium bromide stained rRNA bands are shown as a loading control.

tions such as rainfall, humidity and temperature have been associated with black point $[9,10,11]$ with discolouration proposed to be the result of an enzymatic oxidation of phenolic compounds within the grain [6]. To assist in resolving the controversy surrounding the cause of black point we have used 2-DE to compare the proteome of healthy and black pointed barley grains.

By comparing the proteome of black pointed and healthy grain we identified a novel putative LEA protein which is less abundant in black pointed grain. LEA proteins are an extremely diverse class of proteins which are in part classified by their spatial and temporal association with the embryo and desiccation, respectively [27]. Although prevalent in desiccated seeds, they decrease significantly once germination begins [25]. They are characterised by being rich in hydrophilic amino acids (such as lysine and glycine) ordered in repeated sequences [28], which results in hydrophilic side chains that are thought to interact with, and protect hydrophilic proteins during desiccation by causing aggregation [29]. In an attempt to further understand this diverse group of proteins they have been categorised on the basis of the presence or absence of specific sequence motifs [30]. Where no sequence motif is evident, LEAs are then classified on the basis of significant over-representation of particular peptides in certain combinations (such as AA, QAA, KT, KE and TQ) [30]. The protein isolated in this study had an over-representation of these peptides and was also highly hydrophilic, thus suggesting it is a LEA protein.
To date no full-length LEA protein sequence has been identified in barley that corresponds to the $75 \mathrm{kDa}$ protein identified in this study. However, LEA proteins of 68 and $65 \mathrm{kDa}$ have been isolated from soybean and pea, respectively $[25,31]$. These proteins were found to be biotinylated through an atypical covalent attachment of biotin at a lysine residue within a conserved motif of (V/M)GKF [26]. The proposed purpose of the biotinylation was to act as a biotin sink during desiccation, and then upon germination when this protein is degraded the biotin is released to be used as a cofactor for enzymes involved with germination [25].

Western blot analysis in this study revealed that the identified LEA protein was bound by streptavidin (Fig. 3C), indicating that it is biotinylated in vivo. This suggests that the LEA protein identified may have a similar role as a biotin sink as proposed in the pea and soybean studies [25, 31]. Increased LEA protein in healthy grains is not a result of different levels of gene transcription (Fig. 4) but likely due to the LEA protein being degraded in black pointed grains especially given transcript levels were higher in black pointed grain than healthy grain. With respect to black point development it suggests that grains with this condition have entered into the germination process where LEA is usually degraded [25]. Monitoring LEA levels during grain development and in response to environmental conditions conducive to black point development could be used to investigate this hypothesis.

Black point formation can first be observed on green grain prior to desiccation and has also been associated with increased rainfall and moisture during grain fill [9]. One possibility, therefore, is that environmental conditions are prolonging the period of grain development in black pointed grain. This in turn may allow the grain to over develop [32] and the embryo enters into a germination state resulting in the breakdown of LEA proteins. This notion of black pointed grains being over developed is supported by evidence that black pointed wheat grains are larger than healthy grains, possibly as a result of prolonged endosperm development [33]. 
The discolouration observed at the embryo end of the grain could therefore be a result of the over developed embryo wounding the surrounding tissues. Previous observations of damaged germ aleurone tissue identified dark-brown discolouration which was proposed to be due to enzymatic oxidation of phenolic compounds by peroxidase enzymes [34]. In pearl millet grains it has been observed that during grain development the embryo crushes the surrounding transfer cells resulting in a dark pigmentation on the surface of the grain [35]. A similar phenomenon may result in black pointed grain if an enlarged embryo wounds the overlying germ aleurone cells.

In support of enzymatic oxidation induced by wounding we also identified that barley grain peroxidase 1 (BP1) was more abundant in black pointed grains. BP1 belongs to the class III group of peroxidase enzymes (EC 1.11.1.7), which are secreted into the extracellular space or the vacuole of plant cells [36]. BP1 contains both an Nterminal and C-terminal signal peptide that target it to the secretory pathway and vacuole, respectively. BP1 is a unique plant peroxidase in that it is inactive at $\mathrm{pH}>5$. Due to this, it has been proposed that BP1 is targeted to the vacuole rather than the cell wall as the vacuole provides an acidic environment. At its optimum $\mathrm{pH}, \mathrm{BP} 1$ is able to oxidise the main phenolic compounds present in barley grain, ferulic and $p$-coumaric acid, into discoloured endproducts [12].

In this study BP1 was identified as two separate spots on the 2-D gel with a MW difference of approximately $1 \mathrm{kDa}$. This has been observed before when BP1 was purified from barley grain as two distinct sized proteins [37]. The larger of the two proteins was found to be glycosylated.

BP1 gene expression has previously been reported to be high early in grain development and ceases approximately 27 days after flowering [12]. This has also been confirmed in our research (data not shown). In this present study BP1 transcripts were not detected in either healthy or black pointed grain. This is to be expected in healthy grain but cannot explain the increased levels of BP1 protein in black pointed grain. BP1 protein accumulation has been reported in two studies to be exclusively present in the endosperm at 15-20 days after flowering $[12,38]$. Further research is needed to determine if BP1 accumulation is also confined to the endosperm in black pointed grains.

This present study has provided significant evidence to support the argument that black point is associated with physiological changes within the grain. Understanding precisely what environmental conditions induce black point will be of significant benefit in further understanding the molecular mechanism of the browning. Future research will concentrate on the location of the identified proteins within black pointed and healthy grain using immunolocalisation. Knowledge of this will aid in understanding what is happening within the grain in relation to black point development.
The authors would like to thank Jelle Lahnstein and Christopher Bagley for technical assistance with the 2-D gel electrophoresis experimentation and MS/MS analysis, respectively. This research was funded through the Molecular Plant Breeding Cooperative Research Centre (MPB CRC).

\section{References}

[1] Conner, R. L., Davidson, J. G. N., Resistance in wheat to black point caused by Alternaria alternata and Cochliobolus sativus. Can. J. Plant Sci. 1988, 68, 351-359.

[2] Rees, R. G., Martin, D. J., Law, D. P., Black point in bread wheat - effects on quality and germination, and fungal associations. Aust. J. Exp. Agric. 1984, 24, 601-605.

[3] Cromey, M. G., Mulholland, R. I., Blackpoint of wheat - Fungal associations, cultivar susceptibility, and effects on grain weight and germination. N. Z. J. Agric. Res. 1988, 31, 51-56.

[4] Conner, R. L., Hwang, S. F., Stevens, R. R., Fusarium proliferatum: A new causal agent of black point in wheat. Can. J. Plant Pathol. 1996, 18, 419-423.

[5] Kumar, J., Schafer, P., Huckelhoven, R., Langen, G. et al., Bipolaris sorokiniana, a cereal pathogen of global concern: Cytological and molecular approaches towards better control. Mol. Plant Pathol. 2002, 3, 185-195.

[6] Williamson, P. M., Black point of wheat: In vitro production of symptoms, enzymes involved, and association with Alternaria alternata. Aust. J. Agric. Res. 1997, 48, 13-19.

[7] Jacobs, B., Rabie, C. J., The correlation between mycelial presence and black-point in barley. Phytophylactica 1987, 19, 77-81.

[8] Basson, A. B. K., de Villiers, O. T., Rabie, C. J., Effect of black ends on quality characteristics of Clipper barley and malt. $J$. Am. Soc. Brew. Chem. 1990, 48, 8-13.

[9] Petr, J., Capouchova, I., Causes of the occurrence of malting barley kernel discoloration. Monatsschrift fur Brauwissenschaft 2001, 54, 104-113.

[10] Conner, R. L., Influence of irrigation and precipitation on incidence of black point in soft white spring wheat. Can. J. Plant Pathol. 1989, 11, 388-392.

[11] Moschini, R. C., Sisterna, M. N., Carmona, M. A., Modelling of wheat black point incidence based on meteorological variables in the southern Argentinean Pampas region. Aust. J. Agric. Res. 2006, 57, 1151-1156.

[12] Rasmussen, C. B., Henriksen, A., Abelskov, A. K., Jensen, R. B. et al., Purification, characterization and stability of barley grain peroxidase BP1, a new type of plant peroxidase. Physiol. Planta. 1997, 100, 102-110.

[13] Sosulski, F., Krygier, K., Hogge, L., Free, esterified and insoluble-bound phenolic acids. 3. Composition of phenolic acids in cereal and potato flours. J. Agric. Food Chem. 1982, 30, 337-340.

[14] Regnier, T., Macheix, J.-J., Changes in wall bound phenolic acids, phenylalanine and tyrosine ammonia lyases, and peroxidases in developing durum wheat grains (Triticum turgidum L. var. durum). J. Agric. Food Chem. 1996, 44, 1727-1730.

[15] Mak, Y. X., Willows, R. D., Roberts, T. H., Wrigley, C. W. et al., Black Point is associated with reduced levels of stress, dis- 
ease- and defence-related proteins in wheat grain. Mol. Plant Pathol. 2006, 7, 177-189.

[16] Finnie, C., Melchior, S., Roepstorff, P., Svensson, B., Proteome analysis of grain filling and seed maturation in barley. Plant Physiol. 2002, 129, 1308-1319.

[17] Bak-Jensen, K. S., Laugesen, S., Roepstorff, P., Svensson, B., Two-dimensional gel electrophoresis pattern (pH 6-11) and identification of water-soluble barley seed and malt proteins by mass spectrometry. Proteomics 2004, 4, 728-742.

[18] Østergaard, O., Finnie, C., Laugesen, S., Roepstorff, P., Svensson, B., Proteome analysis of barley seeds: Identification of major proteins from two dimensional gels ( $p l$ 4-7). Proteomics 2004, 4, 2437-2447.

[19] Graham, D. R. M., Garnham, C. P., Fu, Q., Robbins, J., Van Eyk, J. E., Improvements in two-dimensional gel electrophoresis by utilizing a low cost 'in-house' neutral pH sodium dodecyl sulfate-polyacrylamide gel electrophoresis system. Proteomics 2005, 5, 2309-2314.

[20] Neuhoff, V., Arold, N., Taube, D., Ehrhardt, W., Improved staining of proteins in polyacrylamide gels including isoelectric-focusing gels with clear background at nanogram sensitivity using Coomassie Brilliant Blue G-250 and R-250. Electrophoresis 1988, 9, 255-262.

[21] Speicher, K. D., Kolbas, O., Harper, S., Speicher, D. W., Systematic analysis of peptide recoveries from in-gel digestions for protein identifications in proteome studies. J. Biomol. Tech. 2000, 11, 74-86.

[22] Hong, H. Y., Yoo, G. S., Choi, J. K., Direct Blue 71 staining of proteins bound to blotting membranes. Electrophoresis 2000, 21, 841-845.

[23] Henriksen, A., Welinder, K. G., Gahjede, M., Structure of barley grain peroxidase refined at $1.9-\AA$ resolution. J. Biol. Chem. 1998, 273, 2241-2248.

[24] Duval, M., Pépin, R., Job, C., Derpierre, C. et al., Ultrastructural localization of the major biotinylated protein from Pisum sativum seeds. J. Exp. Bot. 1995, 46, 1783-1786.

[25] Hsing, Y. I. C., Tsou, C. H., Hsu, T. F., Chen, Z. Y. et al., Tissueand stage-specific expression of a soybean (Glycine max L.) seed-maturation, biotinylated protein. Plant Mol. Biol. 1998, $38,481-490$.

[26] Job, C., Laugel, S., Duval, M., Gallardo, K., Job, D., Biochemical characterization of atypical biotinylation domains in seed proteins. Seed Sci. Res. 2001, 11, 149-161.
[27] Roberts, J. K., DeSimone, N. A., Lingle, W. L., Dure III, L., Cellular concentrations and uniformity of cell-type accumulation of two Lea proteins in cotton embryos. Plant Cell 1993, $5,769-780$

[28] Hong-Bo, S., Zong-Suo, L., Ming-An, S., LEA proteins in higher plants: Structure, function, gene expression and regulation. Colloids Surf. B 2005, 45, 131-135.

[29] Goyal, K., Walton, L. J., Tunnacliffe, A., LEA proteins prevent protein aggregation due to water stress. Biochem. J. 2005, $388,151-157$.

[30] Wise, M. J., Tunnacliffe, A., POPP the question: What do LEA proteins do? Trends Plant Sci. 2004, 9, 13-17.

[31] Dehaye, L., Duval, M., Viguier, D., Yaxley, J., Job, D., Cloning and expression of the pea gene encoding SBP65, a seedspecific biotinylated protein. Plant Mol. Biol. 1997, 35, 605621

[32] Royo, C., Abaza, M., Garc de Moral, L. F., Triticale grain growth and morphometry as affected by drought stress, late sowing and simulated drought stress. Funct. Plant Biol. 2000, 27, 1051-1059.

[33] Dimmock, J. P. R. E., Gooding, M. J., The effects of fungicides on Hagberg falling number and blackpoint in winter wheat. Crop Prot. 2002, 21, 475-487.

[34] Cochrane, M. P., Observations on the germ aleurone of barley phenol oxidase and peroxidase activity. Ann. Bot. 1994, $73,121-128$.

[35] Fussell, L. K., Dwarte, D. M., Structural changes of the grain associated with black region formation in Pennisetum americanum. J. Exp. Bot. 1980, 31, 645-654.

[36] Welinder, K. G., Mauro, J. M., Norskovlauritsen, L., Structure of plant and fungal peroxidases. Biochem. Soc. Trans. 1992, $20,337-340$.

[37] Rasmussen, S. K., Welinder, K. G., Hejgaard, J., cDNA cloning, characterization and expression of an endosperm-specific barley peroxidase. Plant Mol. Biol. 1991, 16, 317-327.

[38] Cochrane, M. P., Paterson, L., Gould, E., Changes in chalazal cell walls and in the peroxidase enzymes of the crease region during grain development in barley. J. Exp. Bot. 2000, $51,507-520$. 